International Journal of Advanced Trends in Computer Science and Engineering

Available Online at http://www.warse.org/IJATCSE/static/pdf/file/ijatcse97922020.pdf

https://doi.org/10.30534/ijatcse/2020/97922020

\title{
Edugame Application as Vocabulary Learning Media for Deaf Children
}

\author{
Endah Sudarmilah ${ }^{1}$, Wyne Habsari ${ }^{2}$, Fatah Yasin Al Irsyadi ${ }^{3}$, Wiwien Dinar Pratisti ${ }^{4}$ \\ ${ }^{1,2,3}$ Informatics Department, Faculty of Communcation and Informatics, \\ Universitas Muhammadiyah Surakarta, Indonesia \\ ${ }^{4}$ Psychology Faculty, Universitas Muhammadiyah Surakarta, Surakarta, Indonesia, Universitas Muhammadiyah \\ Surakarta, Indonesia \\ Endah.Sudarmilah@ums.ac.id ${ }^{1}$,wynehab29@gmail.com², Yasin@ums.ac.id ${ }^{3}$ Wiwien.Pratisti@ums.ac.id ${ }^{4}$
}

\begin{abstract}
Reading activity has tremendous impacts and benefits in sharpening and increasing one's intelligence. Each individual is entitled to the opportunity to be able to read, both those who are normal and those who have disabilities, such as the one with hearing impairment or deaf. Hearing impediment often causes a setback or even loss of speech because the sufferer has a deficiency or loss of hearing ability either partial or total. The problem encountered by the deaf person breeds the idea of developing learning applications for people with disabilities especially children. This research aims to make it easier for children to understand and foster vocabulary acquisition as well as to develop children's motivation in the learning process as this learning media is designed with an attractive and interactive interface. Edugame application which emphasized an android-based visual form was established as a support to the development of children's speech and reading skills. The development method used in designing this application is the prototyping model which consists of the needs analysis, prototype design, prototype evaluation, program writing/coding, program testing, program evaluation, and implementation. Edugame as vocabulary learning media for deaf children promotes an interesting and interactive learning process to improve children's understanding of words in learning vocabulary. The results of the black box testing, pre-test and post-test, paired sample t-test, SUS, and Aiken V revealed that all the results were valid, so it could be concluded that there were significant differences (real) before and after the use of the application in the learning process.
\end{abstract}

Key words : Application, construct, edugame, vocabulary, reading, prototype, deaf, visual.

\section{INTRODUCTION}

The reading activity has a big impact on human life. It benefits and enriches people's understanding of various words around them and makes them more intelligent [1].
Someone with reading ability will have a greater opportunity to develop the skills and understand each subject matter which increases the insight that can be used to overcome challenges in the future [2]. Based on this statement, all people are entitled to the opportunity to be able to read, both normal people and those with special needs [3].

People with hearing impairment or deafness are those who have a hearing impediment due to damage or loss of the ability to hear either in part or complete which may be caused by nerve damage or malfunctioning of the hearing instrument [4]. Discordant to normal individuals, people with disabilities are usually less optimal in comprehending learning material [5]. Deaf people have a hearing impediment that leads to deterioration or even loss of speech. Such limitations have caused some difficulties such as difficulty in obtaining information, processing words, and learning difficulties [6], [7]. Those existing problems give rise to the idea of developing learning applications for deaf children. This research aims to ease children in understanding words and fostering vocabulary acquisition as well as developing children's motivation in the learning process since the learning media are designed with an attractive and interactive interface.

\section{LITERATURE REVIEW}

Technology has become an inseparable part of human activity and has influenced many fields, including education [8]. Technology advancement is frequently used as a learning tool in the educational settings which is expected to make it easier for someone to find information, including for those with special needs [9], [10], [11], [12].

Smartphones are often used as a means of entertainment, one of which is to play games. Initially, people assume that the game only gives negative impact on youngsters by violence and exposing hostile characters [13], but today its development reveals other uses of the game such as the means of learning (edugame), the media expresses a variety of creativity by various individuals, business land, simulations, and e-sports [10], [14], [15], [16]. The learning media in the form of an android application is chosen as an alternative, in 
addition to its progressiveness it has also become a necessity that is used in any activities [17]. Portability is one of the benefits of mobile games, which can be played anywhere.

The application of learning media requires supporting tools so that the program works effectively and interactively. Construct2 is a 2D platform based on HTML5 that is specialized for creating games quickly through the drag-and-drop procedure [18]. Users do not need to master special programming languages because Construct 2 features focus on the logic. Construct 2 can be published on various platforms, from web stores, mobile on Android, IOS, and desktop PCs [19].

The development method is selected to create a product based on the results of the needs analysis carried out previously and provide guidance through the stages to be passed [20]. The SDLC (Software Development Life Cycle) method is the foundation in the software development process, with a modified prototype model [21]. Prototyping is a strategy to solve problems or possible problems in the system before taking up more resources [22]. The prototyping method can be applied to create simple or complex applications so that the implementation process can run orderly as it is scheduled [23].

Arum Kurnia Sulistyawati in her research entitled "Perancangan User Interface Aplikasi Kamus Bahasa Isyarat Tematik Berbasis Mobile Application" argued that the purpose of her research was to produce a mobile application that could facilitate students learning sign language by preparing groups of vocabulary based on certain themes [11]. The research concluded that the application of sign language learning could still be developed into other applications that were aligned with the needs of students according to the existing education curriculum.

This triggered the researchers of this current research to create a similar application that is under the curriculum needs at MIM PK Kartasura namely to know various vocabulary based on similar themes that are considered important to be taught to deaf children.

This current research emphasizes the visual form that makes it easier for children to understand and foster vocabulary acquisition [17], [24], [25], [26]. Learning media is also designed with an attractive and interactive interface [27], the use of this application is also expected to develop students' motivation in the learning process [28], develop language skills, and reduce or overcome communication problems [17].

\section{METHOD}

This research used a prototype development method. The prototype method was used as a design method which was the basis or standard for the next stage and was used to reflect or imagine the final system of the application being made. The procedures included:

\subsection{Functional and Non-Functional Requirements Analysis}

Functional requirements contain what processes can later be carried out by the system or application. Several functions that can be performed by the vocabulary edugame application are the user can select the menu and display the page according to the selected menu, the user can select the vocabulary sub-menu according to the desired theme, the user can play the game based on the open level, the application can display the instruction for an educational game, the application can display pop-up sound settings, and the application creates sound according to the running actor.

Non-functional requirements analysis explains what is needed by a system to make it runs as expected. This stage provides information on what system to be used, what hardware should be included, and what software to be installed. Some of the non-functional requirements applied in this research were laptop, smartphone, construct2, CorelDraw, and web browser.

\subsection{Prototyping}

This stage would translate requirements for software including interface representation and data structure before coding. The current researchers used an Object-Oriented Design (OOD) based design consisting of:

\section{a. Use Case Diagram System}

Use case diagram gives an overview of the functionality of the device that is expected to meet user needs [11]. In this use case, the writers presented an actor, namely students and assistants/teachers as users of the edugame application. Activities carried out by the user can be seen in Figure 1

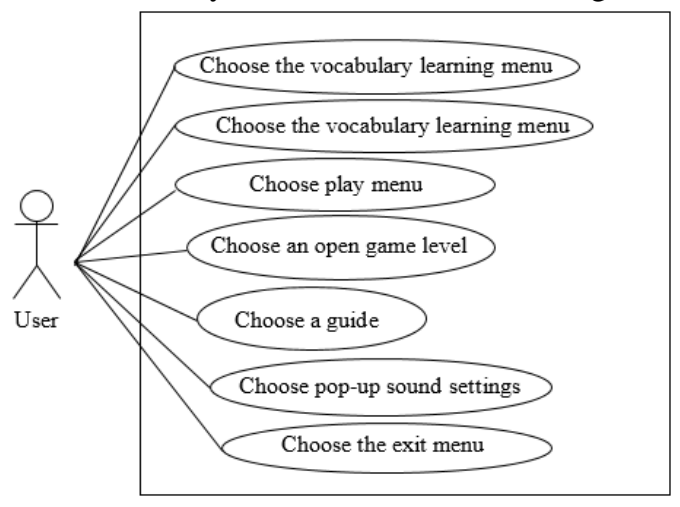

Figure 1: Use Case Diagram System

\section{b. Flowchart Design}

A flowchart is a representation of the stages of software or applications making logically. Flowchart 
presentation is carried out systematically through capturing information based on the procedures presented in the form of graphic depictions. Flowcharts are used by programmers to help and solve problems into smaller parts [29]. The flowchart in Figure 2 shows that the application is started by displaying the main page that contains menus, such as the learning button for vocabulary learning, the play button to practice, the info button that explains the use of the application, the settings button to adjust the sound, and the exit button to close the application.

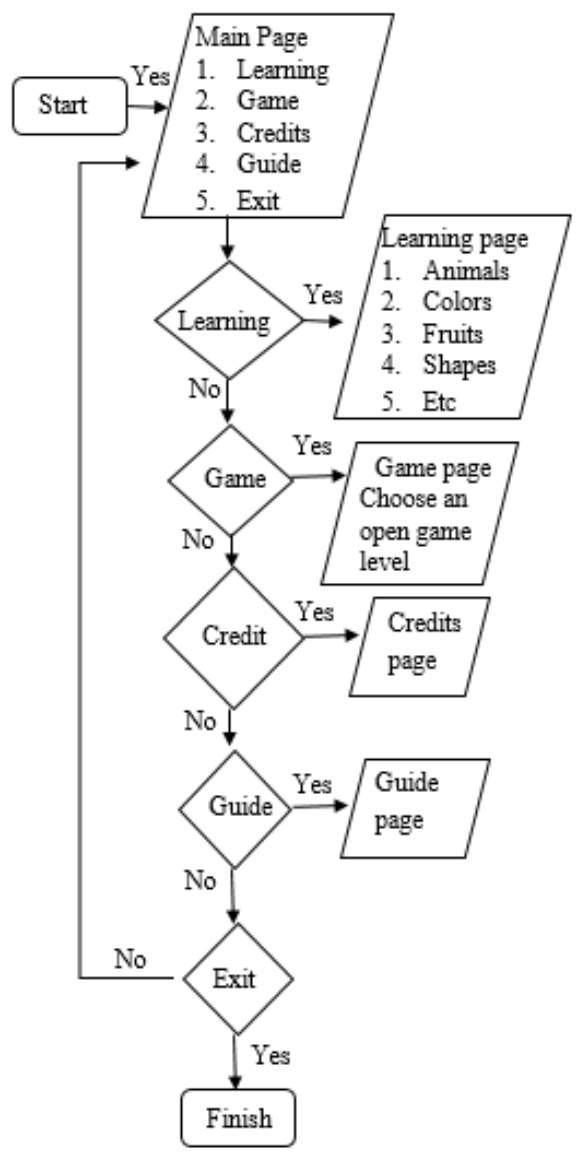

Figure 2: Flowchart

\section{c. Storyboard Design}

A storyboard is a sketch or picture that illustrates the idea of a series of concepts or ideas to describe the order of the flow of applications that are built [30].

\subsection{Prototype Evaluation}

At this stage, the researchers evaluated whether the prototyping design of the vocabulary edugame application matched the needs analysis or check whether there were parts that needed to be added or changed so that the application could be developed as it was expected.

\subsection{Creating the Program}

At this stage, the researchers assembled all the assets or multimedia materials based on the design stage starting from use case, flowchart to the storyboard. The creation of assets and interfaces was done by using Corel Draw software while the implementation of the application was carried out with Construct2.

\subsection{Creating the Program}

Vocabulary edugame application that had been created was then tested to find out whether the analysis of functional requirements had been fulfilled or not, whether there were missing functions, interface errors and other errors. Edugame application testing phase consisted of BlackBox testing, questionnaires, as well as pre-test and post-test. The Blackbox testing method could efficiently test software functionality. Testing by questionnaire can evaluate objects easily and quantitatively [31].

\subsection{Implementation}

After the application was tested, the system was evaluated. This part is necessary to complete the deficiencies of the application and make it easier to make improvements on the application so that it functions well.

\subsection{Program Evaluation}

This is the process by which the program was ready to use to support the learning of deaf children with special needs, in this case students with hearing impairment (deaf) at MIM PK Kartasura.

\section{RESULTS AND DISCUSSION}

\subsection{Main Page}

The main page consists of a learning button to select vocabulary based on themes, play button to start the game, exit button to close the application, a credit button (!) contains an explanation of application development, a guide button (?) to find out how to play the game, and a settings button to change the sound. Main page can be seen in Figure 3.

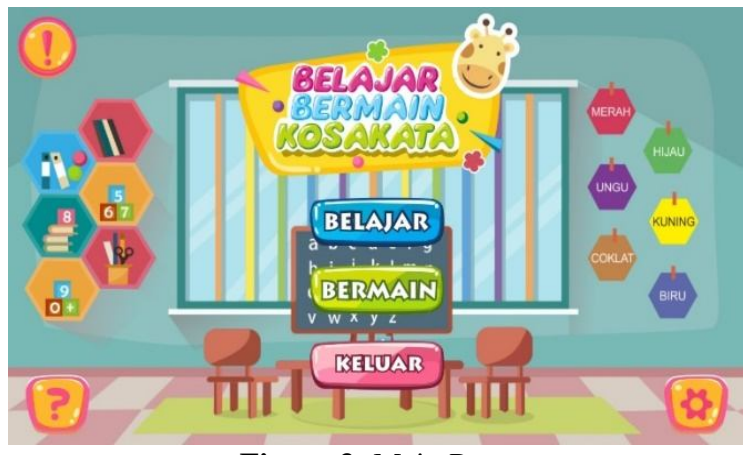

Figure 3: Main Page 


\subsection{Learning Page}

The learning page contains the vocabulary sub-theme buttons that you want to choose. This page consists of $7 \mathrm{sub}$ vocabulary themes, namely the names of animals, colors, vehicles, fruits, school objects, numbers, and shapes. In addition to the sub-theme button, there is also a home button to return to the main page and a settings button to display pop-up sounds. Learning page can be seen in Figure 4.

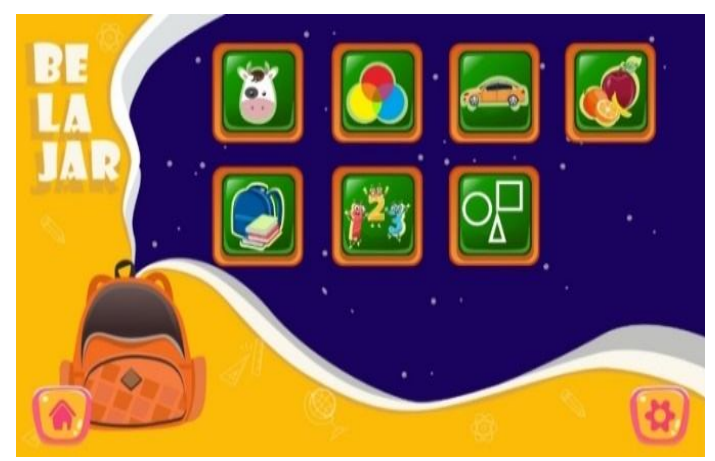

Figure 4: Learning Page

\subsection{Sub-theme Animal Names Page}

The learning page for the names of animals will appear when the user selects an animal picture menu. This page displays pictures of animals according to the names listed below, each time the user presses the back button $(<<)$ or next $(>>)$ the image will change and be followed by dubbing pronunciation of the animal's name. Sub-theme animal names page can be seen in Figure 5.

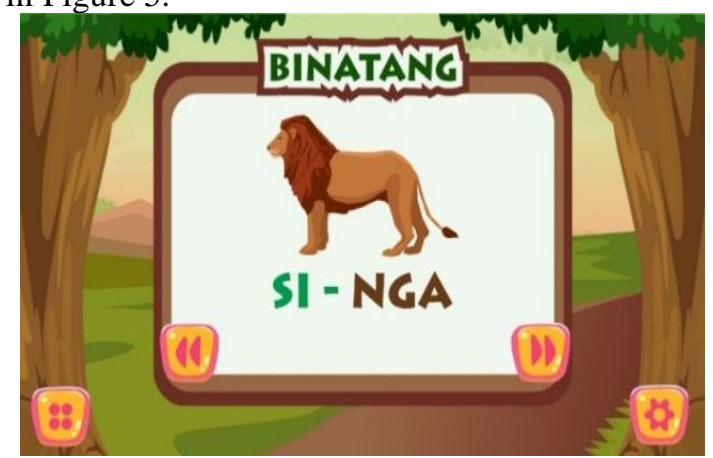

Figure 5: Sub-theme Animal Name Page

\subsection{Playing Page}

The playing page displays the level menu in map form. Each time the level is completed, the next level menu will open so it can be played. If the level menu is still in the padlock, then the previous level must be completed first. Playing page can be seen in Figure 6.

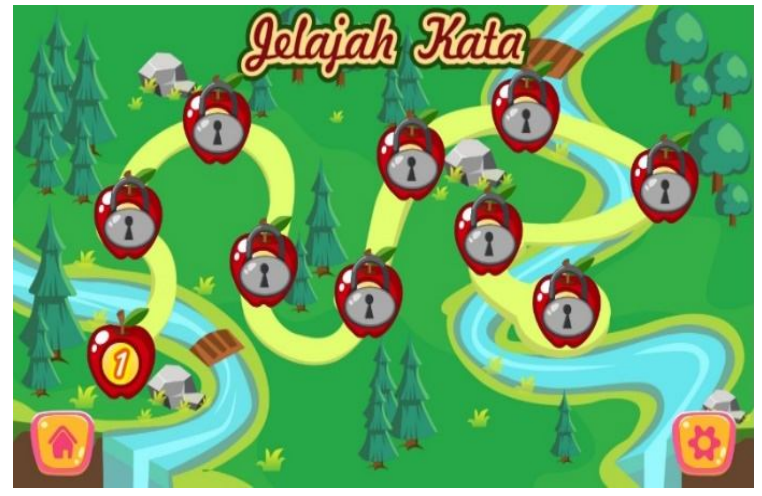

Figure 6: Playing Page

\subsection{Level 1 and Reward Page}

Level 1 playing page contains the game with the easiest level. If the user can put the fruit image in the right place, the picture will be installed in its place. But if the user mistakenly puts the fruit image in its place, then the fruit image will bounce and return to the starting place. After all the images are installed a reward will appear along with the next button to proceed to level 2. Level 1 and reward page can be seen in Figure 7 and Fiure 8.

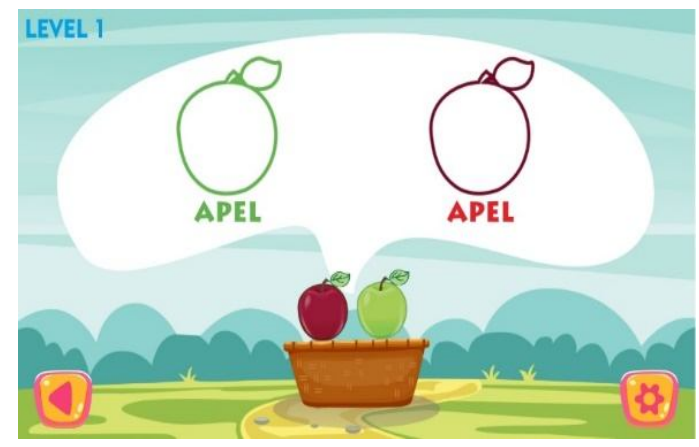

Figure 7: Level 1 Page

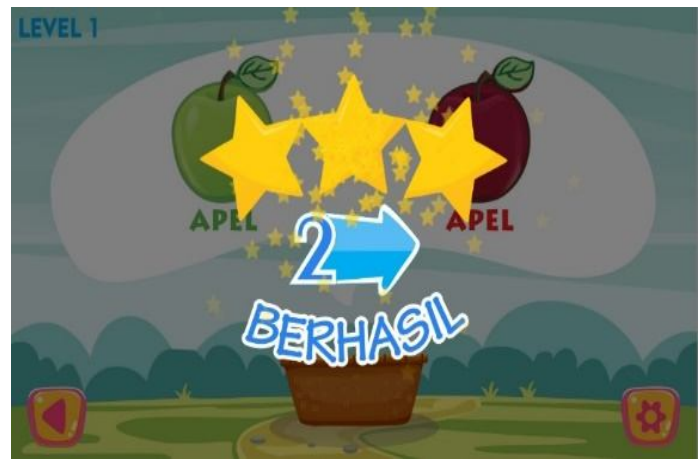

Figure 8: Reward Page

\subsection{Black-box Testing}

The black-box testing method is used to test functionality, in this case, whether the application can run well or not. The results of the testing on one page of the application namely the main page are shown in Table 1. 
Table 1: Black-box Testing Test Results on the main page

\begin{tabular}{|c|c|c|c|c|}
\hline No & $\begin{array}{l}\text { Testing } \\
\text { Button }\end{array}$ & Input & Output & Status \\
\hline 1 & Learning & $\begin{array}{l}\text { Click the learn } \\
\text { button }\end{array}$ & $\begin{array}{l}\text { Enter the } \\
\text { learning } \\
\text { page }\end{array}$ & Valid \\
\hline 2 & Playing & $\begin{array}{l}\text { Click the play } \\
\text { button }\end{array}$ & $\begin{array}{l}\text { Enter the } \\
\text { playing page }\end{array}$ & Valid \\
\hline 3 & Close & $\begin{array}{l}\text { Click the close } \\
\text { button }\end{array}$ & $\begin{array}{l}\text { Close/exit } \\
\text { application }\end{array}$ & Valid \\
\hline 4 & Setting & $\begin{array}{l}\text { Click the } \\
\text { settings button }\end{array}$ & $\begin{array}{l}\text { Display the } \\
\text { sound } \\
\text { settings } \\
\text { pop-up }\end{array}$ & Valid \\
\hline 5 & Music & $\begin{array}{l}\text { Click the } \\
\text { music button }\end{array}$ & $\begin{array}{l}\text { Turn on or } \\
\text { turn off the } \\
\text { back sound }\end{array}$ & Valid \\
\hline 6 & Audio & $\begin{array}{l}\text { Click the } \\
\text { audio button }\end{array}$ & $\begin{array}{l}\text { Turn on or } \\
\text { turn off the } \\
\text { audio button }\end{array}$ & Valid \\
\hline 7 & Close (x) & $\begin{array}{l}\text { Click the close } \\
\text { button }\end{array}$ & $\begin{array}{l}\text { Close the } \\
\text { pop-up }\end{array}$ & Valid \\
\hline 8 & $\begin{array}{l}\text { Credits } \\
(!)\end{array}$ & $\begin{array}{l}\text { Click the } \\
\text { credits button }\end{array}$ & $\begin{array}{l}\text { Enter the } \\
\text { credits page }\end{array}$ & Valid \\
\hline 9 & Guide (?) & $\begin{array}{l}\text { Click the } \\
\text { guide button }\end{array}$ & $\begin{array}{l}\text { Enter the } \\
\text { guide page }\end{array}$ & Valid \\
\hline
\end{tabular}

Based on the black-box test results as shown in Table 1, the results have already fulfilled the expectations of the researchers, where all the buttons on the main page of the edugame application function and run well.

\subsection{Pre-test and Post-test}

This test aims to see the extent to which students understand the material before and after using the edugame application. A pre-test was given to students before the researchers demonstrated the application. After demonstrating the application, students were given a post-test question. The pre-test and post-test results are shown in Table 2.

Table 2: The Results of Students' Pre-test and Post-test

\begin{tabular}{lcc}
\hline No & Pre-test & Post-test \\
\hline 1 & 7 & 9 \\
2 & 6 & 10 \\
3 & 7 & 10 \\
\hline Mean & 6.6667 & 9.6667 \\
\hline
\end{tabular}

The test results in Table 2 show the difference in descriptive mean on the pre-test and post-test results. The mean scores obtained by students before and after the implementation were 6.6667 and 9.6667. These results indicate that there is a mean difference between the pre-test and post-test results.

\subsection{Pre-test and Post-test}

In addition to the mean pre-test and post-test as shown in Table 2, a hypothesis test was also performed to see the change of the mean score by using the paired sample t-test. This method is used to compare the difference in the mean of two paired cases in a group of people [32]. The case of paired data that is often appeared is that one individual has 2 types of sample data [33]. The results of the paired sample t-test can be seen in Table 3.

Table 3: Paired Samples T-test

\begin{tabular}{|c|c|c|c|c|c|c|c|c|}
\hline & \multicolumn{5}{|c|}{ Paired Differences } & \multirow{3}{*}{$\mathbf{t}$} & & \multirow{3}{*}{$\begin{array}{l}\text { Sig. } \\
(2-t a \\
\text { iled })\end{array}$} \\
\hline & \multirow[t]{2}{*}{ Mean } & \multirow[t]{2}{*}{$\begin{array}{l}\text { Std. } \\
\text { Devi } \\
\text { atio } \\
\text { n }\end{array}$} & \multirow[t]{2}{*}{$\begin{array}{l}\text { Std. } \\
\text { Error } \\
\text { Mean }\end{array}$} & \multicolumn{2}{|c|}{\begin{tabular}{|c|}
$95 \%$ \\
Confidence \\
Interval of the \\
Difference \\
\end{tabular}} & & & \\
\hline & & & & Lower & Upper & & & \\
\hline $\begin{array}{l}\text { Pair 1 } \\
\text { Pre-test } \\
\text { and } \\
\text { Post-test }\end{array}$ & -3.00 & 1.00 & .57735 & -5.48 & -.516 & -5.196 & 2 & .035 \\
\hline
\end{tabular}

Paired sample t-test table above is the main table that shows the output data. This section is important as the output data will indicate whether or not there is an influence of the use of the application on the vocabulary of the students with hearing impairment. Based on the output from Table 3. the t-obtained (2-tailed) is 0.035 which means the value of sig. (2-tailed) $<0.05$. From these results, it can be concluded that there is a significant (real) difference between the mean scores of the pre-test and post-test results dealing with the use of this vocabulary application [32].

\subsection{Usability Testing on Children Questionnaire (User)}

Usability testing is used to find out how easy, effective, and efficient an application is in helping users achieve their goals. This test was carried out on 3 (three) deaf students of grade 1 at MIM PK Kartasura. The questionnaire uses the System Usability Scale (SUS), which is used to measure the usefulness of the application following the user's subjective point of view. The scores ranging from 1-5 (1: Strongly Disagree, 2: Disagree, 3: Neutral, 4: Agree, 5: Strongly Agree). The results of the user questionnaire can be seen in Table 4.

The mean score was calculated with the following formula:

Mean $=\sum_{i=1}^{n} \frac{x i}{N}$

Where xi is: Respondents' scores, and $\mathrm{N}$ : the number of respondents. The mean score of this SUS testing is $180 / 3=$ 61.3 which means it is in the "good" category. The classification of the score can be seen in Table 5 . 
Table 4: Calculation Results with the SUS Formula

\begin{tabular}{lcccccccccccc}
\hline & \multicolumn{10}{c}{ Questions } & & \multirow{2}{*}{ SUS } \\
\cline { 2 - 8 } & $\mathbf{P}$ & $\mathbf{P}$ & $\mathbf{P}$ & $\mathbf{P}$ & $\mathbf{P}$ & $\mathbf{P}$ & $\mathbf{P}$ & $\mathbf{P}$ & $\mathbf{P}$ & $\mathbf{P}$ & Total & Score \\
& $\mathbf{1}$ & $\mathbf{2}$ & $\mathbf{3}$ & $\mathbf{4}$ & $\mathbf{5}$ & $\mathbf{6}$ & $\mathbf{7}$ & $\mathbf{8}$ & $\mathbf{9}$ & $\mathbf{1 0}$ & & \\
\hline 1 & 4 & 1 & 5 & 1 & 5 & 1 & 4 & 2 & 4 & 1 & 28 & 56 \\
2 & 5 & 2 & 5 & 2 & 5 & 2 & 5 & 1 & 5 & 2 & 34 & 68 \\
3 & 5 & 1 & 5 & 1 & 5 & 1 & 5 & 1 & 5 & 1 & 30 & 60 \\
\hline
\end{tabular}

Total SUS score

184

Where :

P1 : I like this game application so that I will play it more

P2 : This game is too complicated to play

P3 : This game is easy to play

P4 : I need assistance to play this game (can't play alone without help)

P5 : I consider parts of this game can be played well

P6 : I consider this game is confusing regarding how to play it

P7 : I believe other people can learn how to play this game very quickly (easily)

P8 : I consider this game is impractical/difficult to play

P9 : I think I can play this game

P10 : I need to learn a lot to be able to play this game

Table 5: Interval Scale of Percentage Interpretation $(\mathrm{P})$

\begin{tabular}{l|ccccc}
\hline Percentage & $0-20 \%$ & $21-40 \%$ & $41-60 \%$ & $61-80 \%$ & $81-100 \%$ \\
\hline Description & $\begin{array}{l}\text { Very } \\
\text { weak }\end{array}$ & Weak & Enough & Good & Very good \\
\hline
\end{tabular}

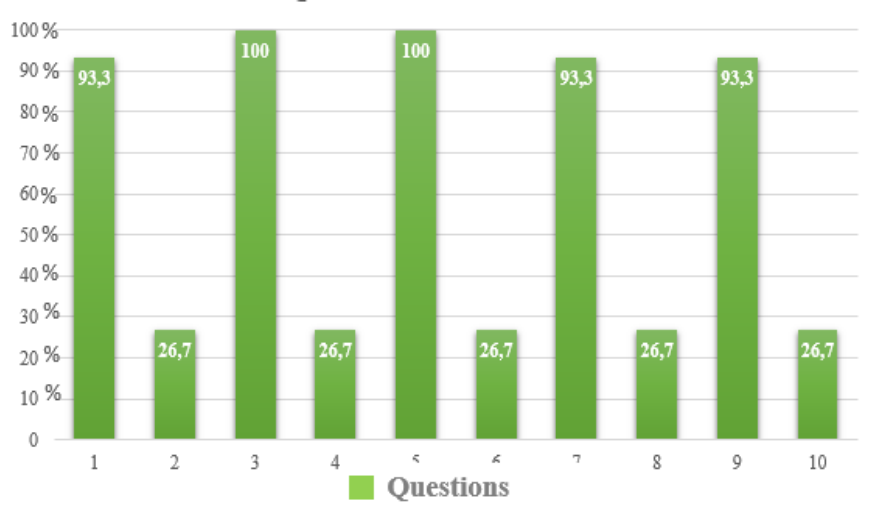

Figure 9: Graph of Questionnaire Results

The questionnaire graph in Figure 9. shows that $93.3 \%$ of respondents said they liked this edugame so that they would play it many times, $26.7 \%$ of respondents thought this edugame was too complicated to play, $100 \%$ of respondents said the application was easy to use, $26.7 \%$ of respondents said they could not play the application alone without the help of others, $100 \%$ of respondents said that the games can be played well, $26.7 \%$ of respondents said the way to play the game is confusing, $93.3 \%$ of respondents said other people would learn to play this game very quickly because it was easy to use, $26.7 \%$ of respondents consider this game was impractical, $93.3 \%$ of respondents said they felt they could play this game, and $26.7 \%$ of respondents said they needed to learn a lot to be able to play this game.

\subsection{Aiken V Test}

In 1986 Aiken formulated an Aiken's V formula that is useful to calculate the results of questionnaires as many as n people on an outcome in terms of the extent to which these items had benchmarks [34]. The calculation of the validity of this research was conducted by teachers who were accompanying the students with. Rating scores ranging from 1 to 5 (1: Strongly Disagree, 2: Disagree, 3: Neutral, 4: Agree, 5: Strongly Agree).

The recommended Aiken $\mathrm{V}$ formula is as follow:

$$
\begin{aligned}
\mathrm{V} & =\sum \frac{s}{[N(\mathrm{c}-1)]} \\
\mathrm{S} & =\mathrm{R}-\mathrm{Lo} \\
\mathrm{Lo} & =\text { The lowest validation score ( for example } 1) \\
\mathrm{C} & =\text { The highest validation score (for example } 5) \\
\mathrm{R} & =\text { The score given by the scorer } \\
\mathrm{N} & =\text { The number of scorers }
\end{aligned}
$$

The test results from Table 6 . show that all $\mathrm{V}$ values are

\begin{tabular}{|c|c|c|c|c|c|c|c|c|}
\hline \multirow{2}{*}{ No } & \multicolumn{2}{|l|}{1} & \multicolumn{2}{|l|}{2} & \multicolumn{2}{|l|}{3} & \multirow{2}{*}{$\sum s$} & \multirow{2}{*}{$\boldsymbol{V}$} \\
\hline & Skor & $\mathbf{S}$ & Skor & $\mathbf{S}$ & Skor & $\mathbf{S}$ & & \\
\hline Q1 & 5 & 4 & 4 & 3 & 5 & 4 & 11 & 0.916 \\
\hline$\underline{Q 2}$ & 5 & 4 & 4 & 3 & 5 & 4 & 11 & 0.916 \\
\hline Q3 & 3 & 2 & 3 & 2 & 3 & 2 & 8 & 0.667 \\
\hline Q4 & 5 & 4 & 5 & 4 & 4 & 3 & 11 & 0.916 \\
\hline Q5 & 5 & 4 & 4 & 3 & 4 & 3 & 10 & 0.833 \\
\hline Q6 & 4 & 3 & 4 & 3 & 5 & 4 & 10 & 0.833 \\
\hline Q7 & 4 & 3 & 3 & 2 & 4 & 3 & 8 & 0.667 \\
\hline Q8 & 5 & 4 & 5 & 4 & 5 & 4 & 12 & 1 \\
\hline Q9 & 5 & 4 & 4 & 3 & 4 & 3 & 10 & 0.833 \\
\hline Q10 & 4 & 3 & 4 & 3 & 5 & 4 & 10 & 0.833 \\
\hline
\end{tabular}
between $0-1$ so that they are considered to have adequate validity and are considered valid. The coefficient with a validation range of $0.58-0.98$ is interpreted as a high coefficient of validity.

Table 6: Aiken V Validation

\section{CONCLUSION}

Based on the results of the research and the discussion of the findings, several conclusions are addressed as follows:

a. Edugame application as vocabulary learning media for deaf children can be used as an interesting and interactive learning media to increase children's mastery in learning vocabulary.

b. The application can be operated by using electronic media such as PCs, Laptops, and Smartphones that use the Android operating system.

c. Based on the pre-test and post-test results using the Paired Sample T-test method, the t-obtained is 0.035 , which means the value of sig. (2-tailed) $<0.05$. It can be concluded that there are significant (real) differences before and after the use of this vocabulary game application. The usability test with the SUS method results in a point of 61.3 which means the application functions well. Also, the Aiken $\mathrm{V}$ test shows that all $\mathrm{V}$ 
values range between $0-1$ so that they are considered to have adequate validity and are considered valid

\section{ACKNOWLEDGEMENT}

This work was supported by Research, Technology and Directorate General of Higher Education (RISTEKDIKTI) of Indonesia, Informatics Department and Electrical Engineering of Universitas Muhammadiyah Surakarta (UMS).

\section{REFERENCES}

1 G. Al Haddar. Peningkatan Minat Baca Anak Melalui Sosialiasi Pentingnya Membaca dan Media Keranjang Buku di Kampung Cerdas, Abadimas Mahakam, vol. 3, no. 02, pp. 109-114, 2019.

2 I. K. Suantara, I. M. Suarjana, and D. N. Sudana. Kecendrungan Minat Membaca Siswa Kelas V SD Negeri 5 Seraya Barat Kecamatan Karangasem, Mimb. PGSD Undiksha, vol. 7, pp. 44-48, 2019.

3 W. Lestari and Zulmiyetri. Meningkatkan Kemampuan Membaca Kata Melalui Media Video Pembelajaran Bagi Anak Tunarungu, J. Penelit. Pendidik. Kebutuhan Khusus, vol. 7, pp. 71-76, 2019.

4 M. Iswari. Career Guidance Model in Independence of Deaf Children in Time After Special Senior High School, J. ICSAR, vol. 1, no. 2, pp. 131-133, 2017.

https://doi.org/10.17977/um005v1i22017p131

5 I. Ratnaningrum and S. Hartati. Utilization of Digital Based Media in Dance Learning for Deaf Students in Inclusicve Elementary School, Educ. Humanit. Res., vol. 303, pp. 169-170, 2019.

https://doi.org/10.2991/icpeopleunnes-18.2019.33

6 F. Soltani, F. Eskandari, and S. Golestan. Developing a gesture-based game for deaf/mute people Using microsoft kinect, in 2012 Sixth Int. Conf. Complex, Intelligent, Softw. Intensive Syst., 2012, pp. 491-495.

7 Y. A. Noermasari and Efendi. Efek Metode Maternal Reflektif terhadap Kemampuan Berbicara Anak Tunarungu, Ortopedagogia, vol. 2, no. 2, pp. 82-85, 2016.

8 M. B. Carnicer. The Use of Educational Data Mining Technique in Technology Assimilation Evaluation: A Response Assessment, Int. J. Adv. Trends Comput. Sci. Eng., vol. 8, no. 3, pp. 654-657, 2019.

https://doi.org/10.30534/ijatcse/2019/50832019

9 W. X. Fen and X. J. Cheng. Using Mobile Learning Way to Support Learning Of The Deaf, in 2010 2nd Int. Conforence Educ. Technol. Comput. Using, 2010, vol. 2, pp. 460-462.

10 E. Sudarmilah, H. Supriyono, U. Fadlilah, F. Ya. Al Irsyadi, and A. Fatmawati. Prototyping AR EduGame for children: learning Indonesian culture, in MATEC Web Conf. AASEC 2018, 2018, vol. 03012, pp. 1-4.

11 A. K. Sulistyawati. Perancangan User Interface Aplikasi Kamus Bahasa Isyarat Tematik Berbasis Mobile Application, J. Teknol. Inf., vol. XIII, no. 3, pp. 39-46, 2018.

12 R. dos P. Canteri, L. S. Garcia, and T. A. Felipe. Conceptual Framework to Support a Web Authoring Tool of Educational Games for Deaf Children, in Proc. ofthe 11th Int. Conf. Comput. Support. Educ. (CSEDU 2019), 2019, pp. 226-235.

13 E. Sudarmilah, U. Fadlilah, H. Supriyono, F. Y. Al Irsyadi, Y. S. Nugroho, and A. Fatmawati. A Review : Is There Any Benefit in Serious Games ?, in AIP Conf. Proc., June 2018, vol. 020059, pp. 1-6.

14 I. Ahmad and W. Widodo. Penerapan Algoritma A Star ( A *) pada Game Petualangan Labirin Berbasis Android, Khazanah Inform., vol. 3, no. 2, pp. 57-63, 2017.

15 A. D. M. Africa, F. M. M. Espiritu, C. R. V Lontoc, R. Jayson, and M. M. Iii. The Integration of Computer Systems into the expansive field of Video Games, Int. J. Adv. Trends Comput. Sci. Eng., vol. 8, no. 4, pp. 1139-1145, 2019. https://doi.org/10.30534/ijatcse/2019/22842019

16 E. Sudarmilah et al. Game Education of Disaster Mitigation: A Systematic Literature Review, Int. J. Adv. Trends Comput. Sci. Eng., vol. 5, no. 6, pp. 2940-2943, 2019.

https://doi.org/10.30534/ijatcse/2019/42862019

17 I. Winaldi and A. Setyawan. Aplikasi Pengenalan Bahasa Isyarat Untuk Penyandang Tuna Tungu Berbasis Android ( Studi Kasus: SLB Madina Serang ), J. Sist. Inf. Vol., vol. 5, no. 2, pp. 70-73, 2018.

18 B. M. M. Alom, C. Scoular, and N. Awwal. Multiplayer Game Design: Performance Enhancement with Employment of Multiplayer Game Design: Performance Enhancement with Employment of Novel Technology, Int. J. Comput. Appl. (0975, vol. 145, no. 1, pp. 27-32, 2016.

19 N. D. Imam and E. Sudarmilah. EduGame Sejarah Islam Masuk Indonesia, J. Ilm. Tek. Elektro, vol. 03, no. 2, pp. 57-62, 2016.

20 D. Effendi, B. Hardiyana, and I. Gustiana. Perancangan Program Aplikasi Pembelajaran IPA Materi Sistem Pernapasan Berbasis Multimedia untuk Siswa SDLB Bagian B Tunarungu Menggunakan Object Oriented Approach, $J$. Simetris, vol. 7, no. 2, pp. 605-618, 2016.

21 E. Sudarmilah, A. Susanto, R. Ferdiana, and N. Ramdhani. Preschoolers , Cognitive Game Prototype, in Proc. 2017 IEEE Int. Conf. Appl. Syst. Innov, 2017, pp. 1875-1878.

22 H. S. Modi, N. K. Singh, and H. P. Chauhan. Comprehensive Analysis of Software Development Life Cycle Models, Int. Res. J. Eng. Technol., vol. 4, no. 6, pp. 117-122, 2017. 
23 D. Purnomo. Model Prototyping Pada Pengembangan Sistem Informasi, JIMP - J. Inform. Merdeka Pasuruan, vol. 2, no. 2, pp. 54-61, 2017.

24 M. Marschark, A. Paivio, L. J. Spencer, A. Durkin, C. Convertino, and E. Machmer. Don't Assume Deaf Students are Visual Learners, HHS Public Access, vol. 29, no. 1, pp. 153-171, 2018.

25 N. Huda and N. A. O. Saputri. Aplikasi Pembelajaran Bahasa Isyarat bagi Penyandang Disabilitas Tunarungu Berbasis Desktop, in Pros. Semin. Nas. Darmajaya, 2018, pp. 19-26.

26 A. Mardiana and T. Wahyuni. Rancang Bangun Aplikasi Android Pengenalan Kosakata untuk Disabilitas Tunarungu enggunakan Metode Sistem Isyarat Bahasa Indonesia, infotech J., vol. 5, no. 1, pp. 64-68, 2019.

27 M. R. Runtulalo, Y. D. Rindengan, and A. S. M. Lumenta. Aplikasi Media Pembelajaran Interaktif Pengenalan Komputer Bagi Anak Tunarungu, $J$. Tek. Inform., vol. 14, no. 2, pp. 209-220, 2019.

28 K. B. A, I. N. Gita, and I. M. Suarsana. Media Pembelajaran Matematika Interaktif untuk Siswa Tunarungu : Perancangan dan Validasi, in Pros. Semin. Nas. Pendidik. Tek. Inform. Ke-8, 2017, pp. 16-22.

29 A. Irdandi, H. Nasution, and A. S. Sukamto. Perancangan Aplikasi Multimedia untuk
Pengenalan Bahasa Isyarat bagi Anak Tunarungu Berbasis Android, J. Sist. dan Teknol. Inf., vol. 5, no. 4, pp. 241-246, 2017.

30 F. Y. Al Irsyadi and A. N. Rohmah. Game Edukasi bagi Anak Autis Bertema Anggota Keluarga Berbasis Kinect XBox 360, J. Simetris, vol. 8, no. 2, pp. 739-746, 2017.

31 Y. Shiono, C. Kato, K. Aoki, and K. Tsuchida. Interactive Visualization System for Psychological Topology, Indones. J. Electr. Eng. Informatics, vol. 7, no. 4, pp. 779-788, 2019.

32 M. Khosravi, N. I. Ali, M. Karbasi, I. A. Brohi, I. A. Shaikh, and A. Shah. Comparison between NFC / RFID and Bar Code Systems for Halal Tags Identification: Paired Sample T-Test Evaluation, Int. J. Adv. Comput. Sci. Appl., vol. 9, no. 4, pp. 221-229, 2018.

33 C. E. J. C. Montolalu and Y. A. R. Langi. Pengaruh Pelatihan Dasar Komputer dan Teknologi Informasi bagi Guru-Guru dengan Uji-T Berpasangan ( Paired Sample T-Test ), J. Mat. dan Apl. deCartesiaN ISSN2302-4224, vol. 7, no. 1, pp. 44-46, 2018.

34 Hendryadi. Validitas Isi: Tahap Awal Pengembangan Kuisioner, J. Ris. Manaj. dan Bisnis Fak. Ekon. UNIAT, vol. 2, no. 2, pp. 169-178, 2017. https://doi.org/10.36226/jrmb.v2i2.47 